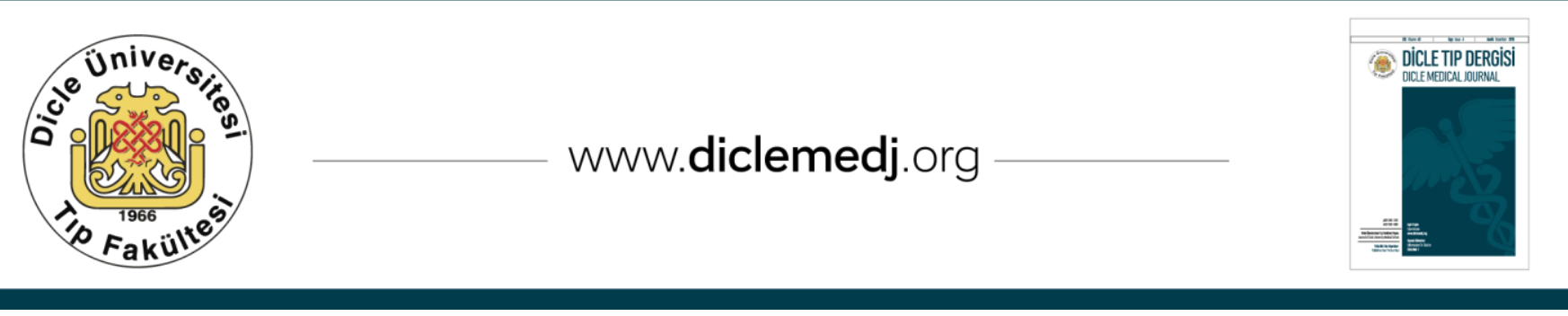

Özgün Araştırma / Original Article

\title{
Akciğer Kanserli Hastalarda Plazma DNA Metiltransferaz ve Metil- CpG'ye Bağlanan Protein Seviyelerinin Değerlendirilmesi
}

\author{
Cansu Özbayer¹, Derya Üstüner², Güntülü Akdoğan Ak³, Faruk Saydam, \\ Muzaffer Metintaş ${ }^{3}$, İrfan Değirmenci ${ }^{5}$ \\ 1 Dumlupınar Üniversitesi Kütahya Sağlık Yüksekokulu, Kütahya, Türkiye \\ 2 Eskişehir Osmangazi Üniversitesi Sağlık Hizmetleri Meslek Yüksekokulu, Eskişehir, Türkiye \\ 3 Eskişehir Osmangazi Üniversitesi Tıp Fakültesi Gögüs Hastalıkları Anabilim Dalı, Eskişehir, Türkiye \\ 4 Recep Tayyip Erdoğan Üniversitesi Tıp Fakültesi Tıbbi Biyoloji Anabilim Dalı, Rize, Türkiye \\ 5 Eskişehir Osmangazi Üniversitesi Tıp Fakültesi Tıbbi Biyoloji Anabilim Dalı, Eskişehir, Türkiye
}

Geliş: 24.10.2016; Revizyon: 13.12.2016; Kabul Tarihi: 09.02.2017

\section{Özet}

Amaç: Akciğer kanseri, akciğer doku hücrelerinin kontrolsüz çoğalmasıyla oluşan ölümcül bir hastalıktır. Çevresel faktörlerle birlikte genetik ve epigenetik değişikliklerin kanser gelişimine neden olduğu bilinmektedir. DNA metilasyonu en önemli epigenetik değişimlerden biri olup, DNA metiltransferaz (DNMT) enzimleri tarafından katalizlenir ve metile-CpG'ye bağlanan proteinler (MBD1, MBD2, MeCP2 vb) yardımıyla gerçekleşir. Çalışmamızda metilasyon ilişkili proteinlerin plazma seviyeleri ile akciğer kanseri riski arasındaki ilişkinin araştırılması amaçlanmıştır.

Yöntemler: Araştırmamızda DNMT1, DNMT2 (TRDMT1), DNMT3A, DNMT3B, MeCP2, MBD1 ve MBD2 seviyeleri, 90 akciğer kanseri hastası (küçük hücreli dışı: 78, küçük hücreli:12) ve 90 kontrol bireyden elde edilen plazma örneklerinde Sandwich-ELISA yöntemi ile ölçüldü. Sonuçlar uygun istatistiksel yöntemler ile değerlendirildi.

Bulgular: Kontrol ve akciğer kanserli hastaların DNMT3a, MBD2 ve MeCP2 seviyeleri arasında fark bulunmamıştır (p>0.05). DNMT1, TRDMT1, DNMT3b ve MBD1 seviyeleri ise kontrol ile karşılaştırıldığında akciğer kanserli bireylerde anlamlı oranda yüksek bulunmuştur $(\mathrm{p}<0.05)$.

Sonuç: Araştırmamız sonucunda yüksek DNMT1, TRDMT1, DNMT3b ve MBD1 plazma seviyeleri ile akciğer kanseri arasında önemli bir ilişsili bulunmuştur. Bulgularımız, hastalığın erken tanısına yönelik araştırmalara katkı sağlayabileceği gibi, metilasyon ilişkili proteinlerin moleküler tanı aracı olarak ta kullanılabileceğini desteklemektedir.

Anahtar kelimeler: Akciğer Kanseri, DNA metiltransferazlar, Metil-CpG'ye Bağlanan Proteinler.

DOI: $10.5798 /$ dicletip. 298604

Yazıșma Adresi / Correspondence: Cansu Özbayer, Dumlupınar Üniversitesi, Kütahya Sağlık Yüksekokulu, 43000, Kütahya, Türkiye Email: c.ozbayer@gmail.com 


\title{
Evaluation of Plasma DNA Methyltransferases and Methy-CpG Binding Protein Levels in Patients with Lung Cancer
}

\begin{abstract}
Objective: Lung cancer is a fatal disease caused by uncontrolled growth of lung tissue cells. It has been known that environmental factors, genetic and epigenetic changes are lead to tumorigenesis. DNA methylation is one of the important epigenetic changes, catalyzed by DNA methyltransferases (DNMTs) and performed with methyl-CpG binding proteins (MBD1, MBD2, MeCP2 etc.). In this study we aimed to determine the association between plasma levels of methylation associated proteins and lung cancer risk.

Methods: The plasma levels of DNMT1, DNMT2 (TRDMT1), DNMT3A, DNMT3B, MeCP2, MBD1 and MBD2 measured with Sandwich-ELISA method in 90 of lung cancer patients (non-small cell: 78, small cell: 12) and 90 of healthy controls. Statistical analysis was performed with appropriate statistical methods.

Results: When comparing the DNMT3a, MBD2 and MeCP2 levels, no significant differences were found between lung cancer patients and controls $(\mathrm{p}>0.05)$. The plasma concentration of DNMT1, TRDMT1, DNMT3b and MBD1 were found to be significantly high in lung cancer patients $(\mathrm{p}<0.05)$.

Conclusion: As a result of our research, we found a significant relation between increased plasma levels of DNMT1, TRDMT1, DNMT3b and MBD1 and lung cancer. It is considered that our findings may contribute to researches for the early diagnosis of lung cancer and support the using of methylation associated proteins as molecular markers.
\end{abstract}

Keywords: DNA Methyltransferases, Methy-CpG Binding Protein, Lung Cancer

\section{GíRiş}

Epigenetik değişiklikler "DNA dizi değişikliği olmadan mayotik ve/veya mitotik olarak kalıtılabilen gen ekspresyon değişiklikleri" olarak tanımlanır ve biyolojik süreçlerde gerekli olan proteinlerin üretilmesi için genlerin açlk, gerekli olmayan proteinleri kodlayan genlerin kapalı durumda kalmasını kontrol eder [1-4].

DNA metilasyonu, en iyi bilinen epigenetik değişimlerden biridir ve ökaryotlarda Sadenozil metionin (SAM) amino asidi kaynaklı bir metil grubunun (-CH3) CpG adacıklarında bulunan sitozinin primidin halkasındaki 5 . karbonuna kovalent olarak bağlanarak 5'metilsitozini oluşturması ile meydana gelir. Reaksiyon, DNA metiltransferazlar (DNMT) adı verilen bir enzim ailesi tarafindan katalizlenir [5-7] ve DNA replikasyonundan sonra gerçekleşir [1,5]. Günümüzde memelilerde DNMT ailesinin; DNMT1, DNMT2, DNMT3a, DNMT3b ve DNMT3L olmak üzere 5 üyesi bulunmaktadır $[4,5]$.
DNMT1, insanda karakterize edilen ilk metiltransferaz enzimidir ve en çok somatik hücrelerde bulunur [8]. DNMT1, DNA replikasyonundan sonra oluşan ve bir yarısı metillenmiş ve yeni sentezlenmiş olan DNA'ya bağlanır ve metillenmemiş zincirde metilasyon kalıplarını oluşturur [1,2,5,9]. Kanser çalışmalarında ilk olarak kolon kanserlerinde DNMT1'in ekspresyonunun arttığı ve DNA metilasyon seviyesinin değiștiği belirtilmiştir $[10,11]$.

DNMT2; DNA'yı metillemek yerine aspartik asit tRNA'sının antikodon ilmeğindeki sitozin-38'i metillediği için günümüzde tRNA aspartik asit metiltransferaz 1 (TRDMT1) olarak isimlendirilmektedir. DNA hasarının tanınması, DNA rekombinasyonu ve mutasyon onarım için gerekli olduğu, eksikliğinde embriyonik kök hücrelerde global DNA metilasyonunun görülmediği belirlenmiştir [7,11,12].

DNMT3a ve DNMT3b, hem yarı metillenmiş DNA'nın metillenmesinden hem de erken gelişim döneminde gözlenen de novo metilasyondan sorumludur $[1,4,5,11,13]$. 
Ayrıca parazitik kaynaklı olarak genoma entegre olan DNA'ların da de novo metilasyonunda görevli oldukları ve bu nedenle konak hücrenin genom savunma mekanizmasını oluşturdukları rapor edilmiştir [2].

DNMT3L metiltransferaz aktivitesi göstermez, ancak DNMT3a ve DNMT3b enzimlerinin aktivitesini düzenleyerek de novo metilasyonu katalizler. DNMT3L gametogenez sirasinda eksprese edilir ve maternal genomik imprintlenmede rol almaktadır $[1,4]$.

DNA metilasyonu ve gen ekspresyonun sessizleşmesi ile ilişkili önemli role sahip olan bir diğer protein ailesi metile $\mathrm{CpG}^{\prime}$ lere bağlanabilen proteinlerdir. Moleküler seviyede ilk olarak belirlenen metile $\mathrm{CpG}^{\prime}$ ye bağlanan protein (methyl-CpG-binding domain-MBD) MeCP2'dir [14]. MeCP2 kromatin ilişkilidir ve genomun yoğun metilenmiş bölgelerine (majör satellit DNA) lokalizedir [15]. MeCP2 haricindeki metile $\mathrm{CpG}$ 'ye bağlanan protein ailesi üyeleri MBD1, MBD2, MBD3 ve MBD4'tür. MBD2 ve MBD4'tür ve MBD yapları bakımından $\% 77$ oranında benzerlik gösterirler [2].

MBD3 dışındaki MBD proteinlerinin tümü in vitro ve in vivo koşullarda metile DNA'yı seçici olarak tanır ve bağlanırlar. MBD3 ise memelilerde MBD bölgesinde kritik bir mutasyona sahiptir ve metile DNA'ya bağlanamaz. Ailenin diğer bir üyesi olan MBD4 ise aslında DNA onarımında görev alan timidin glikozilaz grubu bir onarım enzimidir. Ancak transkripsiyonel represyonda da görev aldığı bildirilmiştir [2].

Metile-CpG'ye bağlanan proteinler, histon modifiye edici enzimler (örn. histon deasetilazlar gibi) ve histon metiltransferazlar gibi ko-represör kompleksleri metillenmiş bölgelere çekerek inaktif kromatin yapının oluşmasına aracılık ederler. Böylece genin transkripsiyonu baskılanmış olur $[10,11]$.
Canlılardaki biyolojik işlevlerde önemli rol oynayan epigenetik dengenin bozulması durumunda kanser gibi birçok patolojik hastalığın ortaya çıkabildiği gösterilmiştir [1,3]. Özellikle ailesel kanser tiplerinde tümör süpresör genlerden birinde kalıtsal olarak eşey hücresi veya somatik hücre mutasyonu bulunur. $\mathrm{Bu}$ mutasyon sebebiyle genin bir kopyası fonksiyonunu kaybeder. Genin ikinci kopyasının kaybı somatik mutasyonlar veya hipermetilasyon ile olabilir [2]. Yapılan çalışmalarda DNMT1 enziminin artması sonucunda $\mathrm{CpG}$ adacıklarındaki metilasyonun arttığı ve CpG adalarının genlerin sıklıkla promotör bölgelerinde bulunması nedeniyle özellikle tümör baskılayıcı genler gibi kanser oluşumunda önemli rol oynayan genlerdeki hipermetilasyonun bu genleri inaktive ederek kanser oluşumuna neden olduğu bildirilmiştir $[1,5]$.

Kanser gelişimi için diğer bir mekanizma genomik hipometilasyondur. Metilasyon ile inaktifleşmiş genler, hipometile olduğunda aktif duruma geçerler. Yapılan çalışmalarda inaktif onkogenlerin tekrar aktive olarak kanser oluşumuna neden olduğu belirtilmiştir [5].

Kanser oluşumunda metilasyon nedenli bir diğer mekanizma; 5meC'nin mutasyon oluşturma riskidir. Normalde DNA daki sitozin bazının deaminasyon ile urasile (U) dönüşmesi yaygin bir mutasyondur ve DNA tamir mekanizmalarınca Urasil-DNA glikosilaz enzimi sayesinde kolaylıkla onarılır. Ancak DNMT enziminin katalizlediği sitozin metilasyonundan sonra oluşan $5 \mathrm{meC}$ deaminasyona uğrarsa timin (T) bazı oluşur. Ancak timin bazı normalde DNA da bulunan bir baz olduğu için tamir mekanizmalarından kaçar ve bu şekilde oluşan nokta mutasyonlarının kanser gelişimini tetiklediği belirtilmiștir [5,16].

Kanser gelişimini birçok şekilde etkileyebilen DNA metilasyonu ile ilişkili enzim ve protein ekspresyonları akut miyeloid lösemi [17], akciğer [18,19], göğüs [20,21], kolorektal ve 
mide [22] kanseri gibi birçok kanser tipi ile ilişkili bulunmuş olup DNMT ve MBD ekspresyonlarının DNA metilasyon düzeyini etkileyerek karsinogenezi etkilediği rapor edilmiştir.

$\mathrm{Bu}$ doğrultuda biz de DNA metilasyonu ve metilasyonun en önemli düzenleyicileri olan DNMT'ler ve MBD'lerin (DNMT1, DNMT2, DNMT3A, DNMT3B, MeCP2, MBD1, MBD2) plazma seviyeleri ile akciğer kanseri riski arasındaki ilişkiyi araştırılmayı amaçladık.

\section{GEREÇ VE YÖNTEMLER}

Çalışmamıza yaş ortalaması 42.8 olan 90 sağlıklı kontrol birey ile yaş ortalaması 62.3 olan 90 akciğer kanseri hastası (küçük hücreli dışı: $n=78$, küçük hücreli: n=12) dahil edilmiștir. Helsinki Deklarasyonu Prensipleri gereğince çalışmanın içeriğiyle ilgili olarak tüm hastalara detaylı bilgi verilerek hastalardan imzalı bilgilendirilmiş onam formu alınmıştır. Çalışmamız için gerekli olan Etik Kurul onayı, Klinik Araştırmalar Etik Kurulu tarafından verilmiştir.

DNMT1, DNMT2 (TRDMT1), DNMT3A, DNMT3B, MeCP2, MBD1 ve MBD2 seviyeleri EDTA'lı tüplere toplanmış olan kandan izole edilen plazma örneklerinde Elabscience (Elabscience Biotechnology Co., Ltd.) enzyme linked immunosorbent assay kit'ler ve Sandwich-ELISA yöntemi ile MultiskanGO UV/VIS (Thermo Scientific, MA, USA) cihazında ölçüldü. Tüm ölçümler kit protokollerine uygun olarak gerçekleştirildi. Özetle; antibody kaplı plate üzerine $100 \mu \mathrm{L}$ standart, örnek ve blank için distile su eklendi, plate'in üzeri filmlenerek $37^{\circ} \mathrm{C}$ 'de $90 \mathrm{dk}$ inkübe edildi. İnkübasyon sonrasında plate içindeki sıvı aspire edildi ve tüm kuyucuklara $100 \mu \mathrm{L}$ Biotinylated Detection Antikoru eklendi ve üzeri filmlenerek $37^{\circ} \mathrm{C}$ 'de $60 \mathrm{dk}$ inkübe edildi. İnkübasyon sonrasında plate içindeki sıvı aspire edildi ve $350 \mu \mathrm{L}$ Wash buffer ile 3 kere yıkandı. Yıkama sonrasında tüm kuyucuklara $100 \mu \mathrm{L}$ HRP Conjugate eklenerek $37^{\circ} \mathrm{C}$ 'de $30 \mathrm{dk}$ inkübe edildi. İnkübasyon sonrasında plate içindeki sıvı aspire edildi ve $350 \mu \mathrm{L}$ Wash buffer ile 5 kere yıkandı. Daha sonra tüm kuyucuklara $90 \mu \mathrm{L}$ Subtrate Reagent eklendi ve $37^{\circ} \mathrm{C}^{\prime} \mathrm{de} 15 \mathrm{dk}$ inkübe edildi ve $15 \mathrm{dk}$ sonrasında tüm kuyucuklara $50 \mu \mathrm{L}$ Stop Solution eklenerek hemen Plate okuyucu spektrofotometrede $450 \mathrm{~nm}$ 'de okundu. Cihaz yazılımı ile standart eğriye göre konsantrasyonlar hesaplandı.

İstatistiksel Analiz

Tüm analizler IBM SPSS Statistics 21 paket programı ile One-way ANOVA yöntemi kullanılarak yapılmış ve 0.05 'den küçük olan $p$ değeri anlamlı kabul edilmiștir.

\section{BULGULAR}

Araştırmamız kapsamında 90 kontrol birey ile 78'i küçük hücreli olmayan ve 12'si küçük hücreli akciğer kanseri hastalığına sahip 90 bireyde DNA metilasyonunda görev alan DNMT1, 3a, 3b, TRDMT1 enzimleri ile MBD1/2 ve MeCP2 protein seviyeleri belirlenmiş olup sonuçların istatistik değerlendirmeleri Grafik1 ve Grafik 2'de yer almaktadır.

\section{DNA metil transferaz seviyeleri}

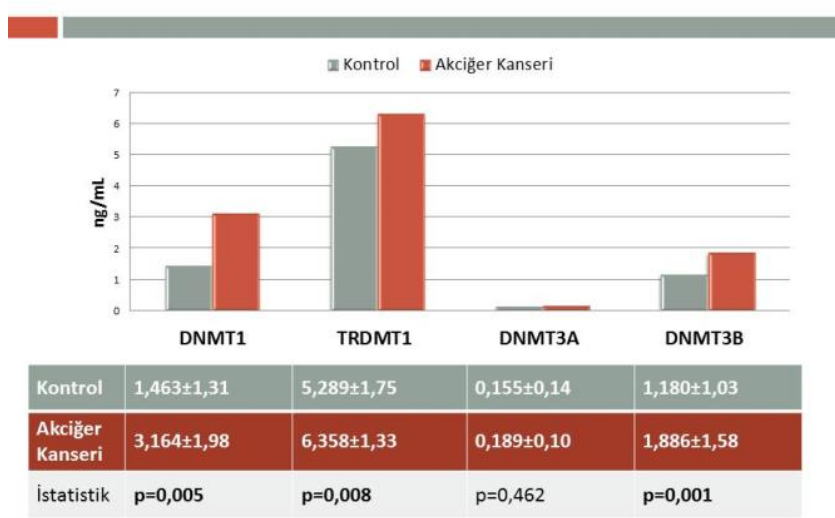

Grafik 1. Akciğer kanserli hastaların ve kontrol bireylerin DNA metil transferaz seviyeleri ve istatistiksel değerlendirmeleri 
Metile-CpG'ye bağlanan protein seviyeleri

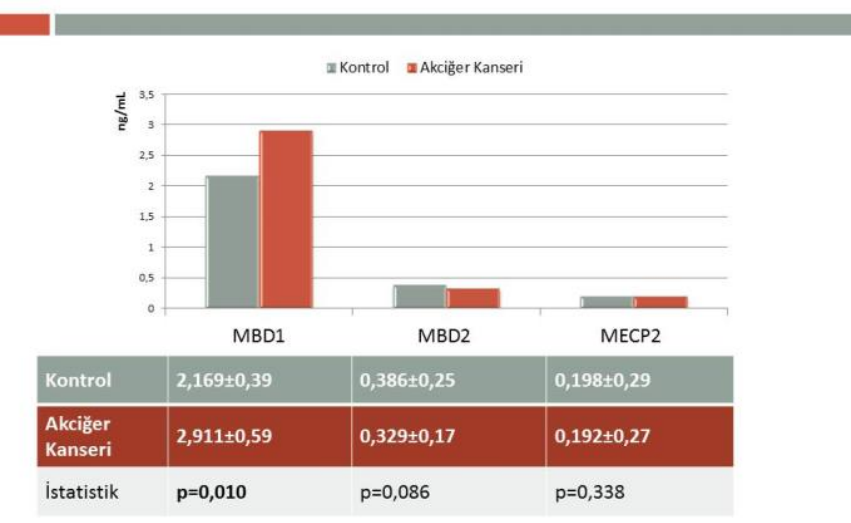

Grafik 2. Akciğer kanserli hastaların ve kontrol bireylerin Metile-CpG'ye bağlanan protein seviyeleri ve istatistiksel değerlendirmeleri

Akciğer kanserli hastaların ve kontrol bireylerin DNA metiltransferaz seviyeleri karşılaştırıldığında; DNMT1 seviyeleri kontrole göre akciğer kanserli hastalarda yüksek bulunmuştur ( $\mathrm{p}=0.005, \mathrm{~F}=8.044)$.

TRDMT1 seviyeleri kontrol grubu ile karşılaştırıldığında akciğer kanserli hastalarda yüksek bulunmuştur ( $\mathrm{p}=0.008, \mathrm{~F}=7.265)$.

Benzer şekilde kontrol ile karşılaştırıldığında

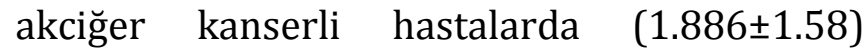
yüksek DNMT3B seviyeleri belirlenmiştir ( $\mathrm{p}=0.001, \mathrm{~F}=12.330)$.

Araştırdığımız bir diğer DNA metiltransferaz olan DNMT3A seviyeleri karşılaştırıldığında ise kontrol $(0.155 \pm 0.14)$ ve hastaların $(0.189 \pm 0.10)$ DNMT3A seviyeleri arasında fark bulunmamıştır ( $\mathrm{p}=0.462, \mathrm{~F}=0.543$ ) (Grafik 1).

Yapılan istatistiksel analiz sonucunda plazma Metile-CpG'ye bağlanan protein seviyeleri değerlendirildiğinde akciğer kanserli bireylerdeki MBD1 seviyelerinin anlamlı oranda yüksek $(\mathrm{p}=0.010, \mathrm{~F}=6.823)$ olduğu belirlenmiştir.

Bununla birlikte kontrol ve akciğer kanserli bireyler arasında MBD2 ( $\mathrm{p}=0.086, \mathrm{~F}=2.979)$ ve MECP2 $(p=0.338, \quad F=0.924) \quad$ seviyeleri yönünden farklılık bulunmamıștır (Grafik 2).

\section{TARTIŞMA}

DNA'nın metilasyonu, DNA metiltransferaz enzimleri tarafından katalizlenir ve metil bağlanma proteinleri yardımıyla gerçekleşir $[1,11]$. Gen ekspresyonu değişikliklerine bağlı olarak DNA metiltransferaz ve MBD proteinlerin seviyelerinde meydana gelen değişiklikler akut miyeloid lösemide [17], akciğer [18,19], göğüs [20,21], kolorektal ve mide [22] kanserlerinin de içinde bulunduğu birçok kanser tipinde rapor edilmiştir.

Memeli hücrelerindeki sitozin bazının metillenmesi DNMT1 enzimi tarafindan katalizlenir ve enzim seviyesinin artması $\mathrm{CpG}$ adacıklarındaki metilasyonun artması ile sonuçlanır. $\mathrm{CpG}$ adaları genlerin sıklıkla promotör bölgelerinde bulunur. Bu nedenle özellikle tümör baskılayıcı genler gibi kanser oluşumunda önemli rol oynayan genlerin promotör dizilerindeki CpG adacıklarında meydana gelen hipermetilasyon bu genleri inaktive eder ve kanser oluşumuna neden olur $[1,5]$.

Kim ve arkadaşları (2006) NSCLC hastalığına sahip bireylerden alınan akciğer dokularında DNMT1 ekspresyonunun arttığını ve DNMT1 seviyelerindeki değişikliklerin NSCLC için bağımsız bir prognostik faktör olabileceğini rapor etmiş̧lerdir [23]. Çalışmamızda da akciğer kanserli bireylerde artmış DNMT1 seviyeleri belirlenmiş olup, yüksek DNMT1 seviyelerinin tümör baskılayıcı gen hipermetilasyonu ile akciğer kanserini etkilediği düşünülmektedir.

DNA hasarının tanınması, DNA rekombinasyonu ve mutasyon onarıminda görevli olan TRDMT1 aspartik asit tRNA'sinın antikodon ilmiğendeki sitozin-38'i metiller [12]. Yapılan çalışmalarda, DNA'yı metillememesine rağmen TRDMT1'in eksikliğinde embriyonik kök hücrelerde global DNA metilasyonu gerçekleşmediği bu nedenle epigenetik kontrol için önemli role sahip olduğu bildirilmiştir [7,12]. TRDMT1'in kanser gelişimine etkisi net olarak tanımlanmamış 
olmakla birlikte yapılan çalışmalarda TRDMT1'in RNA metillenmesini etkileyerek kanser gelişimini etkileyebileceği ifade edilmektedir [24]. Çalışmamızda da akciğer kanserli bireylerde artmış TRDMT1 seviyeleri belirlenmiş olup, TRDMT1'in hipermetilasyon yolu ile kanser gelişimine etki ettiği düşünülmektedir.

DNMT3a hem yarı metillenmiş DNA'nın metillenmesinden hem de erken gelişim döneminde gözlenen de novo metilasyondan sorumludur [2]. Hepatoma, prostat kanseri, kolorektal kanser ve göğüs kanseri gibi birçok kanser tipinde DNMT3a'nın aşırı eksprese olduğu belirtilmiştir [25]. Çalışmamızda akciğer kanseri ve kontrol bireylerin plazma DNMT3a seviyeleri arasında farklılık bulunmamıştır.

DNMT3b DNA metilasyonunda önemli rol oynayan bir de novo metiltransferaz olup, yapılan çalışmalarda DNMT3b'nin, akciğer kanseri [26], skuamöz hücreli baş ve boyun kanseri [27], gögüs kanseri [28], özefagal ve gastrik kanser [29] gibi birçok kanser tipi ile ilişkili olduğu ve özellikle aşırı ekspresyonunun karsinogeneze önemli etkisi olduğu belirlenmiştir [29]. Benzer şekilde çalışmamızda da akciğer kanserli bireylerde artmış DNMT3b seviyeleri belirlenmiş olup, DNMT3b seviyelerindeki artışın tümör baskılayıcı genlerin hipermetilasyonu yoluyla akciğer kanseri gelişimine etki ettiği düşünülmektedir.

Metil-CpG-DNA'ya bağlanan proteinler MeCP2, MBD1 ve MBD2, memeli nüklear proteinlerin önemli bir sınıfını oluştururlar. Bunların arasinda MeCP2 tek ve simetrik olarak metillenmiş $\mathrm{CpG}$ dinükleotidlerine bağlanma yeteneğine sahiptir ve metillenmiş DNA içerdiği bilinen kromozom bölgelerine bağlanır. MBD1 transkripsiyonal bir düzenleyicidir ve tümör süpresörlerin metile $\mathrm{CpG}$ adalarına bağlanarak transkripsiyonu baskılar. MBD2'nin ise DNA demetilaz aktivitesi gösterdiği ve baskılayıcı fonksiyonu olduğu rapor edilmiştir [30].
Kanserde MBD seviyelerinin araştırıldığı sınırlı sayıda çalışma bulunmakla birlikte akciğer kanserinde metil-CpG-DNA'ya bağlanan protein seviyelerinin değerlendirildiği araştırmaya rastlanmamıştır. Bununla birlikte insan prostat kanserlerinde MBD1 protein ekspresyonunun arttığı, MBD2 ve MeCP2 mRNA'larının ise sessizleşmiş olduğu rapor edilmiştir [30]. Bizim çalışmamızda ise farklı olarak MBD1 ve MeCP2 protein seviyeleri ile akciğer kanseri arasında bir ilişki bulunmamış, bununla birlikte MBD2 protein seviyelerinin akciğer kanserli bireylerde anlamlı oranda arttığ tespit edilmiştir. MBD2 proteininin tümör süpresörleri baskıladığı bilinmekte [30] ve akciğer kanserinde de MBD2 protein seviyelerinin artmış olmasının tümör süpresör baskılanması ile ilişkili olabileceğini düşündürmektedir.

Çalışmamızın en önemli sonucu plazma DNMT1, TRDMT1, DNMT3b ve MBD1 seviyelerinin akciğer kanserli bireylerde anlamlı oranda yüksek olmasıdır. DNMT1 ve DNMT3b ile ilgili literatürde benzer bilgiler bulunmakla birlikte TRDMT1 ve MBD1 seviyelerinin akciğer kanseri veya diğer insan kanser türleri ile ilişkisi net değildir. Araştırmamı sonucunda yüksek DNMT1, TRDMT1, DNMT3b ve MBD1 plazma seviyeleri akciğer kanseri arasında anlamlı ilişkili bulunmuştur. Verilerimizin akciğer kanserinin tanı ve tedavisine yönelik araștırmalara veya yeni moleküler biyobelirteçlerin tanımlanmasına katkı sağlayabileceğini düşünmekteyiz.

Çıkar Çatışması Beyanı: Yazarlar çıkar çatışması olmadığını bildirmişlerdir.

Finansal Destek: $\mathrm{Bu}$ çalıșma Eskişehir Osmangazi Üniversitesi Bilimsel Araştırma Projeleri Fonu tarafından desteklenmiştir (Proje no: 201241020) 
Declaration of Conflicting Interests: The authors declare that they have no conflict of interest.

Financial Disclosure: This study was supported by the foundation of scientific research projects (Project number: 201241020)

\section{KAYNAKLAR}

1. Yaykaşlı KO, Hatipoğlu ÖF, Ertuğrul K, Yaykaşlı E. Epigenetik mekanizmalar ve kanser. Dicle Tıp Dergisi. 2012; 14:58-68.

2. Kaymak A: Farklı kanserlerin hücre hatlarında demetilasyon oluşturulması ile tümör süpresör ve stamp ailesi gen ifade değişikliklerinin incelenmesi. Yüksek Lisans Tezi. İzmir: Ege Üniversitesi Sağlık Bilimleri Enstitüsü; 2012.

3. Novik K, Nimmrich I, Genc B, et al. Epigenomics: genome-wide study of methylation phenomena. Current issues in molecular biology. 2002;4:111-28.

4. Onay $\mathrm{H}$ : Konvansiyonel renal hücreli kanser oluşumunda etkili olan genlerin metilasyon durumunun araștırılması. Doktora Tezi. İzmir: Ege Üniversitesi 2006.

5. Çelik S: Kronik miyeloid lösemili hastalarda dap kinaz geninin metilasyon analizleri. Yüksek Lisans Tezi. Ankara: Ankara Üniversitesi, Biyoteknoloji Enstitüsü; 2007.

6. Zakhari S. Alcohol metabolism and epigenetics changes. Alcohol research: current reviews. 2013; 35:616.

7. Subramaniam D, Thombre R, Dhar A, Anant S. DNA methyltransferases: a novel target for prevention and therapy. Frontiers in oncology. 2014; doi: 10.3389/ fonc.2014.00080

8. Robertson KD. DNA methylation and chromatinunraveling the tangled web. Oncogene. 2002; 21:536179.

9. Alberts B, Johnson A, Lewis J, et al.: Molecular biology of the cell, 4th edition edn. New York: Garland Science; 2002.

10. Bozkurt S: Imatinib mesilat-dirençli ve dirençsiz kronik myeloid lösemi hücre hatlarında bim ve bid proapoptotik genlerinin polikomb grup proteinleri tarafından epigenetik regülasyonu. Doktora Tezi. Ankara: Ankara Üniversitesi, Sağllk Bilimleri Enstitüsü 2010.

11. Varol N: Akut Lösemilerde Socs-1 Geninin Metilasyon Analizi. Yüksek Lisans Tezi. Ankara: Ankara Üniversitesi, Sağlık Bilimleri Enstitüsü 2007.
12. Goll MG, Kirpekar F, Maggert KA, et al. Methylation of tRNAAsp by the DNA methyltransferase homolog Dnmt2. Science. 2006;311:395-8.

13. Bodur E, Demirpençe E. Kodlamayan RNA'lar ve gen susturumu. Hacettepe Tip Dergisi. 2010; 41:82-9.

14. Parry L, Clarke AR. The roles of the methyl-CpG binding proteins in cancer. Genes \& cancer. 2011; 2:618-30.

15. Wade PA. Methyl CpG-binding proteins and transcriptional repression. Bioessays. 2001;23:1131-7.

16. Sayin DB. Methylation and cancer: Review. Turkiye Klinikleri Journal of Medical Sciences. 2008;28:513-24.

17. Garzon R, Liu S, Fabbri M, et al. MicroRNA-29b induces global DNA hypomethylation and tumor suppressor gene reexpression in acute myeloid leukemia by targeting directly DNMT3A and 3B and indirectly DNMT1. Blood. 2009; 113:6411-8.

18. Tang M, Xu W, Wang Q, et al. Potential of DNMT and its epigenetic regulation for lung cancer therapy. Current genomics. 2009; 10:336-52.

19. Belinsky SA, Klinge DM, Stidley CA et al. Inhibition of DNA methylation and histone deacetylation prevents murine lung cancer. Cancer Res. 2003;63:7089-93.

20. Lin $X$, Nelson WG. Methyl-CpG-binding domain protein-2 mediates transcriptional repression associated with hypermethylated GSTP1 CpG islands in MCF-7 breast cancer cells. Cancer Res. 2003; 63:498504.

21. Ballestar E, Paz MF, Valle L, et al. Methyl-CpG binding proteins identify novel sites of epigenetic inactivation in human cancer. The EMBO journal. 2003; 22:6335-45.

22. Kanai Y, Ushijima S, Kondo $Y$, et al. DNA methyltransferase expression and DNA methylation of CPG islands and peri-centromeric satellite regions in human colorectal and stomach cancers. Int J Cancer. 2001; 91:205-12.

23. Kim H, Kwon YM, Kim JS, et al. Elevated mRNA levels of DNA methyltransferase-1 as an independent prognostic factor in primary nonsmall cell lung cancer. Cancer. 2006; 107:1042-9.

24. Schaefer M, Hagemann S, Hanna K, Lyko F. Azacytidine inhibits RNA methylation at DNMT2 target sites in human cancer cell lines. Cancer Res. 2009; 69:8127-32.

25. Lin RK, Hsu HS, Chang JW, et al. Alteration of DNA methyltransferases contributes to $5^{\prime} \mathrm{CpG}$ methylation and poor prognosis in lung cancer. Lung Cancer. 2007; 55:205-13. 
Özbayer C., Üstüner D., Akdoğan Ak G., Saydam F., Metintaş M., Değirmenci İ.

26. Shen H, Wang L, Spitz MR, et al. A novel polymorphism in human cytosine DNAmethyltransferase-3B promoter is associated with an increased risk of lung cancer. Cancer Res. 2002; 62:4992-5.

27. Liu Z, Wang L, Wang L-E, et al. Polymorphisms of the DNMT3B gene and risk of squamous cell carcinoma of the head and neck: A case-control study. Cancer Lett. 2008; 268:158-65.

28. Sandhu R, Rivenbark AG, Coleman WB. Enhancement of chemotherapeutic efficacy in hypermethylator breast cancer cells through targeted and pharmacologic inhibition of DNMT3b. Breast Cancer Res Treat. 2012; 131:385-99.
29. Chen MF, Lu MS, Lin PY, et al. The role of DNA methyltransferase $3 \mathrm{~b}$ in esophageal squamous cell carcinoma. Cancer. 2012; 118:4074-89.

30. Patra SK, Patra A, Zhao H, et al. Methyl-CpG-DNA binding proteins in human prostate cancer: expression of CXXC sequence containing MBD1 and repression of MBD2 and MeCP2. Biochemical and biophysical research communications. 2003; 302:759-66. 